\title{
Connexins and intercellular communication in arterial growth and remodeling
}

\author{
Chintamani N. Joshi ${ }^{1}$ and David A. Tulis ${ }^{2 *}$ \\ *Correspondence: tulisd@ecu.edu

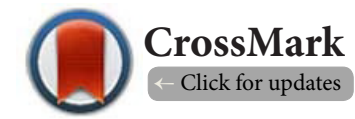

'Department of Pharmacology, S.M.B.T. College of Pharmacy, Nandi Hills, Dhamangaon, Tal. Igatpuri, Nasik 422403 (MS), India. ${ }^{2}$ Department of Physiology, Brody School of Medicine, East Carolina University, Greenville, NC 27834. USA.

\begin{abstract}
Gap junction functionality and intercellular exchange of chemical messengers and other biologically important cellular signals makes communication between adjacent cells possible and is essential for multicellular living systems. This intercellular communication is carried out through gap junction channels that are comprised of multimeric connexin $(\mathrm{Cx})$ proteins and that provide physical linkages between neighboring cells. This Cx-specific gap junction intercellular communication (GJIC) helps perform numerous essential physiological functions in different organ systems. In vascular tissues, reciprocal GJIC between intimal vascular endothelial cells (VECs) and medial vascular smooth muscle cells (VSMCs) helps to control blood flow and arterial pressures by signaling contraction or relaxation events. In the vascular system appropriate GJIC also regulates responses to circulating hormones and other vasoactive factors as well as growth during episodes of stimulated angiogenesis and/or vasculogenesis. Deleterious GJIC, however, serves as a contributing element in vascular pathologies and plays key roles in abnormal vascular cell proliferation, migration, and inflammation, foundational mechanisms of arterial remodeling and neointima development. In this review we discuss the critical roles of vascular gap junction Cx proteins and GJIC in regulating pathologic arterial remodeling.
\end{abstract}

Keywords: Atherosclerosis, connexins, gap junction intercellular communication, inflammation, migration, neointima, pathology, proliferation, vascular remodeling

\section{Introduction}

Biological systems are naturally dynamic, and appropriate cellto-cell communication is necessary for normal physiological functions and in order to maintain homeostasis in an intact living system. Many body functions such as sinus rhythm and cardiac conduction, vascular myogenic tone, skeletal muscle coordination, intestinal movement and motility, and many forms of neuronal transmission require constant communication between cells in order to optimally perform. Specific channels known as gap junctions exist between cells for this transfer of messenger molecules and/or ions through gap junction intercellular communication (GJIC). In the cardiovascular system, disturbances in the expression of gap junction proteins (connexins) and/or functional changes via GJIC have been shown to cause or promote certain disorders such as arrhythmia, diabetes, cardiomyopathy, atherosclerosis and vascular occlusive disorders. In this regard, studies have attempted to fully understand the physiological regulation of and inflammatory mediators involved in cell-to-cell communication and GJIC during atherosclerosis and vascular remodeling. This review article describes the essential roles of gap junction proteins and GJIC in vascular pathology and their significance as potential therapeutic targets in the vascular system.

\section{Review}

\section{Connexins and intercellular communication}

The concept of intercellular communication and its role in the control of cell growth was originally put forth in 1979 by Loewenstein $[1,2]$. Living systems are active, and a constant exchange and interplay of various components between cells and within tissues is necessary in order to maintain a living state. In multicellular organisms, communication between cells plays a critical role in the ability of the tissues to adequately perform their functions. This intercellular communication is vital to maintain normal bodily functions, and in cardiovascular tissues GJIC is involved in many critical processes such as cell differentiation, growth 
Joshi et al. Archives of Physiology 2015,

control, determination and control of vasomotor tone, and coordination of contraction and conduction of cardiac muscle cells [3-5].

The special transmembrane channels that facilitate intercellular communication are known as gap junctions. Gap junctions are comprised of specific transmembrane proteins called connexins $(C x)[6,7]$ which make up a family of structurally-related elements that exist as different types varying with respect to their tissue distribution and molecular weights. About 21 different types of Cx's have been identified in humans [8] and these vary with respect to cellular localization and physiological functions. Cx monomers combine to form hexameric hemichannels called connexons that can associate with connexons on adjacent cells to form integrated and communicative gap junctions that allow the intercellular passage of ions and small molecules via GJIC. Depending on tissue and cell type the gap junction channel can be made up of the same (homomeric) or different (heteromeric) connexin types, and these have different capacities to operate as cellto-cell channels in context-specific fashion.

\section{Connexins in vascular physiology}

In the cardiovascular system, GIC has many functions in normal vessel physiology and maintenance and is also intimately involved during pathophysiological disorders. In VECs and VSMCs, GJIC regulates intercellular ionic coupling and coordinates vascular cell responses to external, paracrine and autocrine stimuli. The transverse and longitudinal signaling regulated by GJIC in vascular beds uniquely allows cellular and often directed exchange of second messengers, metabolites and ions between VECs and VSMCs and maintains normal vascular myogenic tone and tissue function $[4,5,9]$. For example, vasoconstriction from acetylcholine is an integral aspect of the bidirectional cellular communication performed by gap junctions [10]. Additionally, GJIC is important in maintaining cell quiescence [11], endothelial repair [12], and for capillary sprouting that occurs during angiogenesis. An important role played by $\mathrm{Cx} 40$ is in the maintenance of arterial blood pressure [13]. At least four different types of connexins have been reported in VECs and VSMCs $[14,15]$, and with developments in molecular biology it has been found that $\mathrm{C} \times 43$ is more abundant in VSMCs while Cx40 is more abundant in VECs [16], adding to the context-specificity of Cx biology in vascular tissues. The other reported Cx types present in the vasculature are $C \times 37$ and $C \times 45$ [17-19] . In vascular cells Cx43 monomers combine to form hexameric hemichannels that form gap junctions to allow the intercellular passage of ions and small molecules (less than $1 \mathrm{kDa}$ ) such as $\mathrm{Ca}^{++}$, ATP and cyclic AMP [20]. A number of studies have related impairment of $\mathrm{Cx} 37, \mathrm{Cx} 40, \mathrm{Cx} 43$ and/or Cx45 with vascular abnormalities in genetically-deficient mice [21-24]. In fact, some of the $\mathrm{Cx} 43$ deletions are lethal and the embryos do not survive [25], demonstrating an essential role of $C x$ and GJIC in normal tissue function and viability.

\section{Atherosclerotic vascular disease}

Atherosclerosis is the major cause of death in Americans and globally, and its prevalence continues to increase in developing countries. In recent decades, a plethora of information has been obtained regarding mechanisms leading to the initiation, evolution and complication of atherosclerotic lesions. Dysfunction of the vascular endothelium is induced by hypercholesterolemia or other cardiovascular risk factors and is considered the initiating step in the formation of an atherosclerotic plaque. The activated endothelial cells then engage monocytes, T-cells [26] and platelets [27] in the evolution of plaque formation. Several inflammatory mediators also actively participate in the growth of the plaque that ultimately leads to complication with vascular occlusion and subsequent ischemia of downstream tissue. The complications of the disease are basically due to the disruption of the atherosclerotic plaque caused by the erosion of the endothelium and/or rupture of the fibrous cap covering the lipid core [28]. The broken plaque may then embolize to downstream vital organs leading to localized cardiac ischemia, cerebral stroke and/or peripheral vascular obstruction.

Following unsuccessful lifestyle modification (to reduce cardiovascular risk) and/or pharmacologic therapy, vascular intervention such as balloon angioplasty and/or bypass grafting is often employed as a surgical approach to combat vascular occlusion. Unfortunately, iatrogenic stenosis following intervention often occurs, and this is usually described as hypertrophic wound healing [29] and mainly involves two processes: neointimal formation and constrictive remodeling of the vessel wall. The hypertrophic wound healing process begins with the removal of the endothelial layer during balloon expansion and vessel wall dilation. The endothelial layer is antithrombogenic in nature. During vascular intervention, endothelial denudation and medial tearing disrupts this protective lining and creates a pro-thrombogenic environment with exposure of the circulating blood cells to the subendothelial matrix that contains numerous platelet-activating factors such as thrombin, thromboxane, platelet-activating factor and collagen. The generation of thrombin stimulates additional platelet activation [30]. The formed thrombus contains chemotactic and mitogenic factors that serve as a matrix for the migration and proliferation of medial and sometimes adventitial VSMCs [31]. Cytokines and growth factors released from the activated platelets and macrophages contribute to this phenotypic modulation of VSMCs and subsequent migratory and proliferative activities. The transformed VSMCs migrate towards the source of stimulation and start to proliferate, in turn, producing a stenotic neointima. The neointima is then further developed by excessive matrix synthesis and the accumulation of other types of cells such as circulating progenitor cells and myofibroblasts originating from the adventitia $[32,33]$. During this process there is also a gradual loss of the contractile phenotype of the cells in the tunica media and loss of contractile function of the blood 
vessel. Formation of the neointima is followed by inward remodeling of the vascular architecture [34]. Gap junctions play important roles between resident VECs and VSMCs and circulating cells during this vast array of cellular changes in atherogenesis as these components need to communicate with each other in order to result in an aggressive and effective pathological manifestation.

\section{Vascular connexins and inflammation}

As complement to this induction of expression of Cx's and GJIC during atherogenesis, $C x$ 's have been found in several types of circulating inflammatory cells such as macrophages, $[35,36]$ microglia [37] and monocytes [38]. Functional GJIC has also been observed to occur between isolated blood platelets [39]. Following treatment with tumor necrosis factor (TNF)- $\alpha$ or IFN- $\gamma_{\text {, }}$ these monocytic cells stimulate the expression of $\mathrm{Cx} 43$ while neutrophils have been reported to express $\mathrm{Cx} 37, \mathrm{Cx} 40$, and Cx43 $[40,41]$. Thus, both circulating and vessel wall cells express Cx's and have functional gap junction channels, revealing a vital communication network between stationary cells of tissues and circulating cells. Following balloon angioplasty or stenting, a number of inflammatory mediators are released along with the stimulation of macrophages and other inflammatory cells. A well known marker for inflammation, the C-reactive protein (CRP), increases up to 1,000-fold after tissue injury or in response to infection and cancers [42]. CRP also influences the gene expression profile of human VECs and enhances monocyte adhesion to VECs. Additionally CRP has been reported to upregulate $C \times 43$ mRNA expression [43]. Thus connexin expression and GJIC may be altered in inflammation and can be considered to have a role to play in neointimal growth and atherosclerosis.

Inflammation is an inherent component of atherogenesis [44]. As the plaque develops at the endothelial layer it downregulates local VEC and VSMC Cx's and disrupts GJIC [45]. In human umbilical venous endothelial cells (HUVECs) that express Cx32 and Cx40 as well as Cx43, treatment with TNF-a decreased Cx32 mRNA expression and protein, where as this was not observed after treatment with lipopolysaccharide (LPS) or interleukin (IL)-1 $\beta$ [46]. In contrast, leukocytes upon treatment with LPS induced $\mathrm{C} \times 43$ which formed junctions with the endothelial cells [47]. Thus the type of Cx and tissue involved decides the fate of $C x$ modulation during vascular disease. In atherosclerotic plaques, the pattern of $C x$ expression is altered and is not similar to that observed in normal, non-diseased vascular tissue. The endothelia of non-diseased aortas express Cx37 and Cx40 where as in the media $\mathrm{C} \times 43$ is present. As an atheroma advances, the presence of $\mathrm{C} \times 37$ and $\mathrm{C} \times 40$ is also observed in the medial VSMCs and in the macrophages in the lipid core but not in the endothelium covering the plaque. Alternatively Cx43 is also observed in the endothelia at the ends of the plaques and in fewer quantities than found in neointimal cells [48].

\section{Connexins, intercellular communication and neointimal} growth

The first correlation between atherosclerotic vascular disease and Cx43/GJIC in VSM was described in 1995 by Blackburn et al. [49]. In atherosclerotic plaques the phenotype of the cells is changed and leads to the formation of foam cells. In normal vessels $\mathrm{Cx} 43$ is located more towards the adventitia [50], but in atherosclerosis, increased $\mathrm{Cx} 43$ levels were observed in the VSMC's compared to foam cells. Later, this group also reported increased VSMC Cx43 levels in the neointima after vascular injury [50]. In this study, Cx43 expression was upregulated in both the medial and intimal cells yet with more gap junctions in the intima than the media. The $\mathrm{C} x 43$ levels were also higher particularly in the neointima. Vascular remodeling after carotid artery injury is primarily due to the migration and proliferation of VSMCs, unlike atherosclerosis which is largely due to leukocyte infiltration [50]. Inflammation is observed in both conditions-primary atherosclerosis and complications following balloon angioplasty. VSMCs in normal blood vessels are of the contractile phenotype which is an important characteristic of healthy vasculature [51]. Prior to the use of experimental atherosclerotic or carotid injury models, in an in vitro study a change in the phenotype from contractile to synthetic leads to upregulation of Cx43 in VSMC's [52]. The synthetic cells express a number of growth factor receptors that may have a role in modulating $C x$ expression [53]. The presence of $\mathrm{C} x 43$ anti-sense or $\mathrm{C} \times 43$ blocking peptides has been reported to reduce platelet-derived growth factor (PDGF)-BB-induced migration of VSMC's. The Cx43 anti-sense also prevents the PDGF-BB-induced phenotypic changes of porcine VSMCs [5]. These findings suggest that expression of $\mathrm{Cx} 43$ and its function play important roles in the control of VSMC migration.

The progression of restenosis after vascular surgery may also be influenced by thrombosis at the site of the injury. Indeed, increased platelet activation at the site of the injury results in increased PDGF-BB secretion, which then has additional growth-promoting effects on VSMCs [5]. Unfortunately the impact of platelet Cx37 in this pathology has not yet been investigated. Studies of $C x$ as modulators of migration or proliferation suggest that they may play roles in these cellto-cell and/or platelet-to-cell processes via either channel dependent (hemichannel or gap junction channel) or channel independent interactions with cytoskeletal proteins, enzymes or junctional proteins $[\mathbf{5 4 , 5 5 ]}$.

There have been conflicting reports on the role of $\mathrm{Cx} 43$ in neointimal growth and vessel wall remodeling. While some studies suggest that reducing $\mathrm{Cx} 43$ limits neointimal formation, thereby implicating $\mathrm{C} \times 43$ as a positive inducer of vascular remodeling, others have reported that knocking out Cx43 enhances neointimal formation, thereby suggesting growth-inhibitory capacity of $\mathrm{Cx} 43$ in the vasculature $[4,56,57]$. The context and experimental conditions of these studies differ greatly and these results have to be compared carefully 
Joshi et al. Archives of Physiology 2015,

http://www.hoajonline.com/journals/pdf/2055-0898-2-1.pdf

doi: 10.7243/2055-0898-2-1

in order to have a better insight into the exact roles of $\mathrm{Cx} 43$. Hypercholesterolemic mice with partial $\mathrm{C} \times 43$ ablation ( $\mathrm{C} \times 43^{+/-}$/ $\left.\mathrm{LDLR}^{--}\right)$demonstrate reduced neointimal formation compared to mice with normal expression of $\mathrm{C} \times 43\left(\mathrm{C} \times 43^{+/+} / \mathrm{LDLR}^{-/}\right)$ [56]. These findings agree with earlier reports $[4,50,58]$ which showed that vascular injury increases $\mathrm{Cx} 43$ expression, and so approaches to limit $\mathrm{C} \times 43$ expression could lead to a reduction in neointimal growth and prove beneficial. However, these results were dramatically opposite when a complete knockout of Cx43 in VSMCs was used [4]. Here the authors expected a complete deletion of $\mathrm{Cx} 43$ in almost all SMC systems, but mosaic $\mathrm{Cx} 43$ expression was still evident in the media of the KO mice. The authors felt that this could have been due to an incomplete gene deletion when using the Cre system, and in turn residual Cx43 still remains in the vascular media, although it can be considered to be less than the $\mathrm{Cx} 43$ present in $\mathrm{Cx} 43^{+/-} / \mathrm{LDLR}^{-/-}$mice. Some other reasons for these two contrasting results could be differences in the models and animals used, but it does not negate an important role for Cx43 in neointimal growth and cannot be simply labeled as different vascular adaptive processes. Some additional reasons could be the differential, context-specific roles of Cx's in the regulation of cell proliferation and growth.

In injury-induced vessel remodeling, reduction of $\mathrm{Cx} 43$ functionality using a pharmacological modulator carbenoxolone reduced neointimal growth while using a small interfering RNA (siRNA) against $C \times 43$ reduced VSMC proliferation in vitro [57]. This study and other studies to date mostly report the effects on $\mathrm{Cx} 43$ expression and/or localization but generally do not fully address the effects of $\mathrm{Cx} 43$ and GJIC functionality. Thus it is not clear if this increased expression of Cx43 actually causes an increase in GJIC in vivo and if abnormal GIC is indeed the key mediator of these pathological processes (versus Cx expression only).

A similar result could relate to a decrease in Cx expression and neointimal formation when the species under study is changed. It has been reported that balloon injury induces Cx40 mRNA and protein expression in neointimal VSMCs in the New Zealand white rabbits $[\mathbf{5 9}, \mathbf{6 0}]$. In other studies in the presence of statins, known to possess anti-inflammatory and anti-proliferative properties, the formation of the neointima induced by balloon injury is reduced along with a decrease in the expression of $\mathrm{Cx} 43$ and $\mathrm{Cx} 40$ at the site of injury [59]. Similarly, the angiotensin-converting enzyme inhibitor ramipril has been effective in inhibiting neointimal formation after balloon injury along with the down-regulation of $\mathrm{Cx} 43$ mRNA and protein [60] in New Zealand white rabbits. One other study, although not directly involving vascular injury, has suggested that inducing hypercholesteromia in rabbits reduces the levels of Cx43 in the VSMC's of rabbits compared to their normal counterparts [61]. This observation could indirectly refer to a change in cellular phenotype due to alteration in normal Cx43 levels in VSMCs in the presence of increased cholesterol levels.
The turnover of $\mathrm{Cx}$ proteins is relatively fast with half-lives ranging from 1 to $5 \mathrm{~h}$ [8]. The protein expression of Cx's as well as functional GJIC may be controlled differently by chemokines that stimulate cell growth. In our recent study aimed at understanding the regulation of Cx43 expression and functionality with respect to VSMC growth in the presence of cyclic nucleotides [62], we observed that although both cyclic AMP and cyclic GMP increased Cx43 expression, only the agonist $8 \mathrm{Br}$-cyclic AMP increased GJIC and at the same time was effective in reducing VSMC growth, suggesting that a closer relationship exists between vascular cell proliferation and GJIC than between vascular growth and Cx protein expression alone. The increase in the levels of $\mathrm{C} \times 43$ has been observed as early as the $1^{\text {st }}$ day after vascular injury in the media on the luminal side [50] and this increase is maintained even in the fully developed neointima. The reason for this increase in $\mathrm{Cx} 43$ could be related to the release of prothrombogenic factors such as thrombin by the endothelium after injury. Thrombin has been shown to stimulate $\mathrm{Cx} 43$ expression in cultured VSMC's $[63,64]$. Secondly, the neointimal cells are phenotypically altered, growing in response to an injury that could release growth factors that enhance $C x$ expression and self-stimulate [63-65]. The VSMC cell line A7r5 is obtained after modifying embryonic rat thoracic aortic VSMCs, and gap junction permeability is reduced in these proliferating cells [67]. Changes in the cellular phenotype have been shown to reduce gap junction communication; thus, this decrease could be a stimulating factor to increase the turnover rate of Cx43. Decreased GJIC may lead to negative feedback with respect to intercellular communication via the Cx's stimulating the increase in Cx43 expression in response to the altered rapidly proliferating neointimal cells or synthetic cells than the normal tissue.

Following vascular injury in the carotid artery, local VSMCs respond by initially replicating in the media and later by migrating to the neointima and subsequently proliferating there $[44,68]$. Proliferation and migration are separate events yet share common mechanistic foundations. Some subpopulations of cells may proliferate in the media before migrating while others may migrate directly, without proliferating initially $[45,69]$. In order to migrate, it is important that cells shed their links with their neighbors and in the process lose their cell-to-cell contacts including gap junctions. The loss of gap junctions in a number of cell types has been associated with cell division $[46,70]$; thus, reduced GJIC has been widely linked to rapid proliferation and uncontrolled growth. Some cancer cells have been reported to show gap junction loss compared to non-cancerous tissues, and the transfection of Cx's into transformed cells has been reported to restore GJIC and suppress tumor growth in nude mice [7]. From this background, lack of gap junctions might be expected to typify the synthetic state of VSMCs during rapid growth.

\section{Conclusions and future directions}

This article presents a brief overview of the role of Cx's and 
GIC in the multifaceted pathology of vascular remodeling. Up until around 2009, there was considerable interest in the genetic and/or molecular modulation of $\mathrm{Cx} 43$ expression in cardiovascular and other body systems. More recently, though, the focus of many studies has been in the pharmacological modulation of $\mathrm{Cx} 43$ expression and function. Connexins and GJIC are vital to normal physiological functions, and the therapeutic value of manipulating Cx expression and/ or GJIC is clear; however, there is clear separation between expression and function in terms of Cx biology and its impact on cardiovascular tissues. The principal hurdle is the differential regulation of Cx's and their GJIC which is most likely context-specific and largely dependent on local metabolic and physiological status. Another major limitation lies in the experimental models available with which to conduct experiments to study active GJIC. Cellular communication is an extremely dynamic process, and to date only several experimental approaches exist (including FRAP, Lucifer yellow transfer, and dye microinjection) that are available for basic and clinical scientists. Primarily, studies are needed to address the time-dependent role and interplay of inflammation and growth with cellular communication after vascular injury. Although a few studies have defined time-dependent Cx expression after vascular disease or injury, whether this increased expression affects GIC and overall gap junction biology is unknown. Increasing our understanding with respect to the roles of vascular cell connexins and their functionality in vessel disease, injury and inflammation is essential for new and exciting developments in the field.

\section{List of abbreviations}

Cx: Connexin

GIC: Gap junction intercellular communication

VEC: Vascular endothelial cell

VSMC: Vascular smooth muscle cell

LDLR: Low density lipoprotein receptor

PDGF: Platelet-derived growth factor

HUVEC: Human umbilical venous endothelial cells

Competing interests

The authors declare that they have no competing interests.

\section{Authors' contributions}

\begin{tabular}{|l|c|c|}
\hline Authors' contributions & CNJ & DAT \\
\hline Research concept and design & $\checkmark$ & -- \\
\hline Collection and/or assembly of data & $\checkmark$ & -- \\
\hline Data analysis and interpretation & $\checkmark$ & $\checkmark$ \\
\hline Writing the article & $\checkmark$ & $\checkmark$ \\
\hline Critical revision of the article & $\checkmark$ & $\checkmark$ \\
\hline Final approval of article & $\checkmark$ & $\checkmark$ \\
\hline Statistical analysis & -- & -- \\
\hline
\end{tabular}

\section{Acknowledgement and funding}

This project was supported by Award Number R01HL81720 from the National Heart, Lung, and Blood Institute, National Institutes of Health (DT), an ECU Brody School of Medicine Seed/Bridge Grant (DT), and a Brody Brothers Endowment Fund Award (DT). The content is solely the responsibility of the authors and does not necessarily represent the official views of the National Heart, Lung, and Blood Institute, the National Institutes of Health, or the Brody Brothers Endowment Fund. We also thank Dr. A. S. Dhake, Principal, S.M.B.T. College of Pharmacy, Dhamangaon, Nasik for providing resources to carry out this work (CJ).

\section{Publication history}

Editors: Juraj Gregan, University of Vienna, Austria.

Paul H. Goldspink, Medical College of Wisconsin, USA.

Received: 25-Nov-2014 Final Revised: 15-Dec-2014

Accepted: 02-Jan-2015 Published: 08-Jan-2015

\section{References}

1. Loewenstein WR. Junctional intercellular communication and the control of growth. Biochim Biophys Acta. 1979; 560:1-65. | Article | PubMed

2. Mehta PP, Bertram JS and Loewenstein WR. Growth inhibition of transformed cells correlates with their junctional communication with normal cells. Cell. 1986; 44:187-96. I Article I PubMed

3. Yamasaki H, Krutovskikh V, Mesnil M and Omori Y. Connexin genes and cell growth control. Arch Toxicol Suppl. 1996; 18:105-14. | Article | PubMed

4. Liao Y, Regan CP, Manabe I, Owens GK, Day KH, Damon DN and Duling BR Smooth muscle-targeted knockout of connexin43 enhances neointimal formation in response to vascular injury. Arterioscler Thromb Vasc Biol. 2007; 27:1037-42. | Article | PubMed

5. Chadjichristos CE, Morel S, Derouette JP, Sutter E, Roth I, Brisset AC, Bochaton-Piallat ML and Kwak BR. Targeting connexin 43 prevents platelet-derived growth factor-BB-induced phenotypic change in porcine coronary artery smooth muscle cells. Circ Res. 2008; 102:65360. | Article | PubMed

6. Kumar NM and Gilula NB. The gap junction communication channel. Cell. 1996; 84:381-8. | Article I PubMed

7. Yamasaki $\mathrm{H}$ and Naus $\mathrm{CC}$. Role of connexin genes in growth control. Carcinogenesis. 1996; 17:1199-213. | Article | PubMed

8. Saez JC, Berthoud VM, Branes MC, Martinez AD and Beyer EC. Plasma membrane channels formed by connexins: their regulation and functions. Physiol Rev. 2003; 83:1359-400. | Article | PubMed

9. Coutinho P, Qiu C, Frank S, Tamber K and Becker D. Dynamic changes in connexin expression correlate with key events in the wound healing process. Cell Biol Int. 2003; 27:525-41. I Article | PubMed

10. Figueroa XF and Duling BR. Gap junctions in the control of vascular function. Antioxid Redox Signal. 2009; 11:251-66. | Article I PubMed Abstract I PubMed Full Text

11. Zhang W, DeMattia JA, Song H and Couldwell WT. Communication between malignant glioma cells and vascular endothelial cells through gap junctions. J Neurosurg. 2003; 98:846-53. | Article | PubMed

12. Kwak BR, Pepper MS, Gros DB and Meda P. Inhibition of endothelial wound repair by dominant negative connexin inhibitors. Mol Biol Cell. 2001; 12:831-45. | Article | PubMed Abstract | PubMed Full Text

13. de Wit C, Roos F, Bolz SS, Kirchhoff S, Kruger O, Willecke K and Pohl U. Impaired conduction of vasodilation along arterioles in connexin40deficient mice. Circ Res. 2000; 86:649-55. | Article | PubMed

14. Evans WH and Martin PE. Gap junctions: structure and function (Review). Mol Membr Biol. 2002; 19:121-36. | Article | PubMed

15. Johnstone $S$, Isakson B and Locke D. Biological and biophysical properties of vascular connexin channels. Int Rev Cell Mol Biol. 2009; 278:69-118. | Article | PubMed Abstract | PubMed Full Text

16. Little TL, Beyer EC and Duling BR. Connexin $\mathbf{4 3}$ and connexin $\mathbf{4 0}$ gap junctional proteins are present in arteriolar smooth muscle and endothelium in vivo. Am J Physiol. 1995; 268:H729-39. | Article | PubMed

17. Haefliger JA, Nicod P and Meda P. Contribution of connexins to the function of the vascular wall. Cardiovasc Res. 2004; 62:345-56. | Article I PubMed 
Joshi et al. Archives of Physiology 2015,

http://www.hoajonline.com/journals/pdf/2055-0898-2-1.pdf

doi: $10.7243 / 2055-0898-2-1$

18. Saitongdee P, Becker DL, Milner P, Knight GE and Burnstock G. Levels of gap junction proteins in coronary arterioles and aorta of hamsters exposed to the cold and during hibernation and arousal. $J$ Histochem Cytochem. 2004; 52:603-15. | Article | PubMed

19. Isakson BE, Damon DN, Day KH, Liao Y and Duling BR. Connexin40 and connexin43 in mouse aortic endothelium: evidence for coordinated regulation. Am J Physiol Heart Circ Physiol. 2006; 290:H1199-205. | Article I PubMed

20. Laird DW. Life cycle of connexins in health and disease. Biochem J. 2006; 394:527-43. | Article | PubMed Abstract | PubMed Full Text

21. Simon AM, Goodenough DA, Li E and Paul DL. Female infertility in mice lacking connexin 37. Nature. 1997; 385:525-9. | Article | PubMed

22. Simon AM and McWhorter AR. Vascular abnormalities in mice lacking the endothelial gap junction proteins connexin37 and connexin40. Dev Biol. 2002; 251:206-20. | Article | PubMed

23. Liao Y, Day KH, Damon DN and Duling BR. Endothelial cell-specific knockout of connexin $\mathbf{4 3}$ causes hypotension and bradycardia in mice. Proc Natl Acad Sci U S A. 2001; 98:9989-94. | Article | PubMed Abstract I PubMed Full Text

24. Kruger O, Plum A, Kim JS, Winterhager E, Maxeiner S, Hallas G, Kirchhoff S, Traub O, Lamers WH and Willecke K. Defective vascular development in connexin 45-deficient mice. Development. 2000; 127:4179-93. Article I PubMed

25. Reaume AG, de Sousa PA, Kulkarni S, Langille BL, Zhu D, Davies TC, Juneja SC, Kidder GM and Rossant J. Cardiac malformation in neonatal mice lacking connexin43. Science. 1995; 267:1831-4. | Article | PubMed

26. Hansson GK and Libby P. The immune response in atherosclerosis: a double-edged sword. Nat Rev Immunol. 2006; 6:508-19. | Article | PubMed

27. Theilmeier G, Michiels C, Spaepen E, Vreys I, Collen D, Vermylen J and Hoylaerts MF. Endothelial von Willebrand factor recruits platelets to atherosclerosis-prone sites in response to hypercholesterolemia. Blood. 2002; 99:4486-93. | Article | PubMed

28. Virmani R, Burke AP, Farb A and Kolodgie FD. Pathology of the vulnerable plaque. J Am Coll Cardiol. 2006; 47:C13-8. | Article I PubMed

29. Schillinger $M$ and Minar $E$. Restenosis after percutaneous angioplasty: the role of vascular inflammation. Vasc Health Risk Manag. 2005; 1:738. | Article | PubMed Abstract | PubMed Full Text

30. Fager $G$. Thrombin and proliferation of vascular smooth muscle cells Circ Res. 1995; 77:645-50. | Article I PubMed

31. Fernandez-Ortiz A, Badimon JJ, Falk E, Fuster V, Meyer B, Mailhac A Weng D, Shah PK and Badimon L. Characterization of the relative thrombogenicity of atherosclerotic plaque components: implications for consequences of plaque rupture. J Am Coll Cardiol. 1994; 23:1562-9. | Article | PubMed

32. Sata M, Saiura A, Kunisato A, Tojo A, Okada S, Tokuhisa T, Hirai $H$, Makuuchi M, Hirata $Y$ and Nagai R. Hematopoietic stem cells differentiate into vascular cells that participate in the pathogenesis of atherosclerosis. Nat Med. 2002; 8:403-9. | Article | PubMed

33. Shi Y, O'Brien JE, Fard A, Mannion JD, Wang D and Zalewski A. Adventitial myofibroblasts contribute to neointimal formation in injured porcine coronary arteries. Circulation. 1996; 94:1655-64. | Article | PubMed

34. Zargham R. Preventing restenosis after angioplasty: a multistage approach. Clin Sci (Lond). 2008; 114:257-64. | Article I PubMed

35. Levy JA, Weiss RM, Dirksen ER and Rosen MR. Possible communication between murine macrophages oriented in linear chains in tissue culture. Exp Cell Res. 1976; 103:375-85. | Article | PubMed

36. Martin CA, el-Sabban ME, Zhao L, Burakoff R and Homaidan FR. Adhesion and cytosolic dye transfer between macrophages and intestinal epithelial cells. Cell Adhes Commun. 1998; 5:83-95. I Article I PubMed

37. Eugenin EA, Eckardt D, Theis M, Willecke K, Bennett MV and Saez JC. Microglia at brain stab wounds express connexin $\mathbf{4 3}$ and in vitro form functional gap junctions after treatment with interferon-gamma and tumor necrosis factor-alpha. Proc Natl Acad Sci U S A. 2001; 98:4190-5. Article | PubMed Abstract | PubMed Full Text

38. Eugenin EA, Branes MC, Berman JW and Saez JC. TNF-alpha plus IFN- gamma induce connexin43 expression and formation of gap junctions between human monocytes/macrophages that enhance physiological responses. J Immunol. 2003; 170:1320-8. | Article | PubMed

39. Angelillo-Scherrer A, Fontana P, Burnier L, Roth I, Sugamele R, Brisset A, Morel S, Nolli S, Sutter E, Chassot A, Capron C, Borgel D, Saller F, Chanson $\mathrm{M}$ and Kwak BR. Connexin 37 limits thrombus propensity by downregulating platelet reactivity. Circulation. 2011; 124:930-9. | Article | PubMed

40. Branes MC, Contreras JE and Saez JC. Activation of human polymorphonuclear cells induces formation of functional gap junctions and expression of connexins. Med Sci Monit. 2002; 8:BR313-23. | PubMed

41. Zahler S, Hoffmann A, Gloe T and Pohl U. Gap-junctional coupling between neutrophils and endothelial cells: a novel modulator of transendothelial migration. J Leukoc Biol. 2003; 73:118-26. | Article | PubMed

42. Pepys MB and Hirschfield GM. C-reactive protein: a critical update. J Clin Invest. 2003; 111:1805-12. | Article | PubMed Abstract | PubMed Full Text

43. Wang Q, Zhu X, Xu Q, Ding X, Chen YE and Song Q. Effect of C-reactive protein on gene expression in vascular endothelial cells. Am J Physiol Heart Circ Physiol. 2005; 288:H1539-45. | Article | PubMed

44. Lee WY, Allison MA, Kim DJ, Song CH and Barrett-Connor E. Association of interleukin-6 and C-reactive protein with subclinical carotid atherosclerosis (the Rancho Bernardo Study). Am J Cardiol. 2007; 99:99102. | Article | PubMed

45. Hou CJ, Tsai CH and Yeh HI. Endothelial connexins are down-regulated by atherogenic factors. Front Biosci. 2008; 13:3549-57. | PubMed

46. Okamoto T, Akiyama M, Takeda M, Akita N, Yoshida K, Hayashi T and Suzuki K. Connexin32 protects against vascular inflammation by modulating inflammatory cytokine expression by endothelial cells. Exp Cell Res. 2011; 317:348-55. | Article | PubMed

47. Jara PI, Boric MP and Saez JC. Leukocytes express connexin 43 after activation with lipopolysaccharide and appear to form gap junctions with endothelial cells after ischemia-reperfusion. Proc Natl Acad Sci U S A. 1995; 92:7011-5. | Article | PubMed Abstract | PubMed Full Text

48. Kwak BR, Mulhaupt F, Veillard N, Gros DB and Mach F. Altered pattern of vascular connexin expression in atherosclerotic plaques. Arterioscler Thromb Vasc Biol. 2002; 22:225-30. | Article | PubMed

49. Blackburn JP, Peters NS, Yeh HI, Rothery S, Green CR and Severs NJ. Upregulation of connexin43 gap junctions during early stages of human coronary atherosclerosis. Arterioscler Thromb Vasc Biol. 1995; 15:121928. | Article | PubMed

50. Yeh HI, Lupu F, Dupont E and Severs NJ. Upregulation of connexin43 gap junctions between smooth muscle cells after balloon catheter injury in the rat carotid artery. Arterioscler Thromb Vasc Biol. 1997; 17:3174-84. I Article I PubMed

51. Rensen SS, Doevendans PA and van Eys GJ. Regulation and characteristics of vascular smooth muscle cell phenotypic diversity. Neth Heart J. 2007; 15:100-8. | Article | PubMed Abstract | PubMed Full Text

52. Rennick RE, Connat JL, Burnstock G, Rothery S, Severs NJ and Green CR. Expression of connexin43 gap junctions between cultured vascular smooth muscle cells is dependent upon phenotype. Cell Tissue Res. 1993; 271:323-32. | PubMed

53. Saltis J, Thomas AC, Agrotis A, Campbell JH, Campbell GR and Bobik A. Expression of growth factor receptors in arterial smooth muscle cells. Dependency on cell phenotype and serum factors. Atherosclerosis. 1995; 118:77-87. | Article | PubMed

54. Kameritsch P, Pogoda K and Pohl U. Channel-independent influence of connexin 43 on cell migration. Biochim Biophys Acta. 2012; 1818:19932001. | Article | PubMed

55. Matsuuchi $L$ and Naus CC. Gap junction proteins on the move: connexins, the cytoskeleton and migration. Biochim Biophys Acta. 2013; 1828:94-108. | Article | PubMed

56. Chadjichristos CE, Matter CM, Roth I, Sutter E, Pelli G, Luscher 
Joshi et al. Archives of Physiology 2015,

http://www.hoajonline.com/journals/pdf/2055-0898-2-1.pdf

doi: $10.7243 / 2055-0898-2-1$

TF, Chanson M and Kwak BR. Reduced connexin43 expression limits neointima formation after balloon distension injury in hypercholesterolemic mice. Circulation. 2006; 113:2835-43. | Article | PubMed

57. Song M, Yu X, Cui X, Zhu G, Zhao G, Chen J and Huang L. Blockade of connexin $\mathbf{4 3}$ hemichannels reduces neointima formation after vascular injury by inhibiting proliferation and phenotypic modulation of smooth muscle cells. Exp Biol Med (Maywood). 2009; 234:1192-200. | Article | PubMed

58. Plenz G, Ko YS, Yeh HI, Eschert H, Sindermann JR, Dorszewski A, Hofnagel $\mathrm{O}$, Robenek H, Breithardt $\mathrm{G}$ and Severs NJ. Upregulation of connexin43 gap junctions between neointimal smooth muscle cells. Eur J Cell Biol. 2004; 83:521-30. | Article I PubMed

59. Wang L, Chen J, Sun Y, Zhang F, Zhu J, Hu S and Wang DH. Regulation of connexin expression after balloon injury: possible mechanisms for antiproliferative effect of statins. Am J Hypertens. 2005; 18:1146-53. | Article I PubMed

60. Li DQ, Chen WX, Zhou YP and Han Y. Effect of ramipril on the regulation of the expression of connexins $\mathbf{4 0}$ and $\mathbf{4 3}$ in a rabbit model of arterial balloon injury. Mol Med Rep. 2012; 6:565-9. | Article | PubMed

61. Polacek D, Bech F, McKinsey JF and Davies PF. Connexin43 gene expression in the rabbit arterial wall: effects of hypercholesterolemia, balloon injury and their combination. J Vasc Res. 1997; 34:19-30. | PubMed

62. Joshi CN, Martin DN, Shaver P, Madamanchi C, Muller-Borer BJ and Tulis DA. Control of vascular smooth muscle cell growth by connexin 43. Front Physiol. 2012; 3:220. | Article I PubMed Abstract | PubMed Full Text

63. Matsushita T, Rama A, Charolidi N, Dupont E and Severs NJ. Relationship of connexin43 expression to phenotypic modulation in cultured human aortic smooth muscle cells. Eur J Cell Biol. 2007; 86:617-28. | Article | PubMed

64. O'Donnell JJ, 3rd, Birukova AA, Beyer EC and Birukov KG. Gap junction protein connexin43 exacerbates lung vascular permeability. PLOS One. 2014; 9:e100931. | Article | PubMed Abstract | PubMed Full Text

65. Mensink A, de Haan LH, Lakemond CM, Koelman CA and Koeman JH. Inhibition of gap junctional intercellular communication between primary human smooth muscle cells by tumor necrosis factor alpha. Carcinogenesis. 1995; 16:2063-7. | Article | PubMed

66. Mensink A, Brouwer A, Van den Burg EH, Geurts S, Jongen WM Lakemond CM, Meijerman I and Van der Wijk T. Modulation of intercellular communication between smooth muscle cells by growth factors and cytokines. Eur J Pharmacol. 1996; 310:73-81. | Article | PubMed

67. Kurjiaka DT, Steele TD, Olsen MV and Burt JM. Gap junction permeability is diminished in proliferating vascular smooth muscle cells. Am J Physiol. 1998; 275:C1674-82. | Article | PubMed

68. Clowes AW, Reidy MA and Clowes MM. Kinetics of cellular proliferation after arterial injury. I. Smooth muscle growth in the absence of endothelium. Lab Invest. 1983; 49:327-33. | PubMed

69. Clowes AW and Schwartz SM. Significance of quiescent smooth muscle migration in the injured rat carotid artery. Circ Res. 1985; 56:139-45. Article I PubMed

70. Dermietzel R, Yancey SB, Traub O, Willecke K and Revel JP. Major loss of the 28-kD protein of gap junction in proliferating hepatocytes. J Cell Biol. 1987; 105:1925-34. | Article | PubMed Abstract | PubMed Full Text

\section{Citation:}

Joshi CN and Tulis DA. Connexins and intercellular communication in arterial growth and remodeling. Arch Physiol. 2015; 2:1.

http://dx.doi.org/10.7243/2055-0898-2-1 